\title{
THE EFFECT OF VARIOUS COMPOSTS ON SOIL PROPERTIES AND COTTON YIELD
}

\author{
Sayimbetov Alisher \\ Doctor of Philosophy (PhD) in Agricultural Sciences, Docent of the Department Farming, \\ Selection and Seed Breeding of Agricultural Crops, Nukus branch of Tashkent State Agrarian \\ University, Nukus, Karakalpakstan, Uzbekistan \\ Elemesova Nargiza Isataevna \\ Assistant of the Department Farming, Selection and Seed Breeding of Agricultural Crops, Nukus \\ branch of Tashkent State Agrarian University, Nukus, Karakalpakstan, Uzbekistan
}

Article DOI: https://doi.org/10.36713/epra4293

\begin{abstract}
This article presents the positive effects of various composts on soil fertility and cotton productivity. It also describes the use of composts with different proportions of phosphogypsum to various organic materials to ensure the growth and high yield of cotton by improving soil bulk density, porosity, water resistance, structural state and agrochemical properties.

KEYWORDS: soil, fertility, soil properties, bulk density, porosity, compost, cotton yield, yield.
\end{abstract}

\section{INTRODUCTION}

Today, composts along with mineral fertilizers are widely used in the world to grow environmentally friendly products, increase soil fertility, improve its water-physical and agrochemical properties and improve the nutritional status of crops.

Experiments show that crop yields are inextricably linked to the amount of fertilizer applied to the soil. The effectiveness of fertilizers is usually determined by the amount of additional yield obtained from the crop.

In a number of countries around the world it has been found that the use of phosphogypsum and phosphogypsum composts as low-yielding and saline soils as ameliorants and fertilizers increases the yield of winter wheat and vegetable crops by $10-15 \%$. In this regard, it is important to conduct research on the preparation of composts in optimal proportions from phosphogypsum and various organic substances, improve their soil fertility and assimilation of plant nutrients, as well as determine the effect on cotton yield and subsequent effects.
Phosphogypsum is a waste of the technology for the production of phosphoric fertilizers, which is currently accumulating over a large area around plants producing a large number (100-150 million tons) of phosphoric fertilizers and is harmful to the environment. Therefore, the issue of elimination (utilization) of phosphogypsum, which contains nutrients, or its use in agriculture, is becoming more urgent. For this reason, it is important to prepare composts by mixing phosphogypsum with composting organic materials.

Improving soil fertility and obtaining high and environmentally friendly products from crops is one of the key issues today. However, declining soil fertility and depletion of nutrients required for plants in the soil are having negative environmental and economic consequences. One of the most pressing problems today is the effective use of composts of various compositions to restore and improve soil fertility, including the use of phosphogypsum in various proportions, mixed with cattle manure, bird manure, rice and wood sawdust. 


\section{EPRA International Journal of Research and Development (IJRD) Volume: 5 | Issue: 4 | April 2020 \\ - Peer Reviewed Journal}

The more humus in the soil, the better its moisture capacity, structure, heat capacity, thermal conductivity, air and water regimes that create favorable conditions for plant life.

According to K.Mirzazhanov and Sh.Nurmatov [2], soil fertility depends on its physical, agrochemical, hydrothermal, reclamation, agrotechnical and many other properties. The abundance of humus in the soil indicates its fertility, as it contains nitrogen, phosphorus, potassium, carbon dioxide, macro-and micronutrients necessary for the plant in general. Humus determines the macro and microstructure of water-resistant soils, their content (structure) increases where humus is rich, and the increase in structure optimizes the volume mass in the soil, improves water, air, microbiological conditions, which in turn leads to optimization of crop nutrient regime. When used with the addition of mineral fertilizers to organic fertilizers, the amount of humus in the soil increases.

Regular use of organic fertilizers increases the amount of nutrients that plants can absorb in the soil and increases the amount of humus, which prevents it from decomposing quickly.

According to N.M.Ibragimov, D.Otakulova, B.I.Niyazaliev, the applied organo-mineral fertilizers facilitate the use of nutrients by the plant and, as a result, have a positive effect on increasing crop yields.

The composition of compost and its structure play an important role in increasing soil fertility. Properly prepared compost is necessary for plant nutrition, improving the structure of the soil and enriching it, organic and mineral substances $[3 ; 4 ; 5]$.

Therefore, research is needed to study the effect of various composts mixed with phosphogypsum in various proportions on cattle manure, bird droppings, rice and wood chips on the agrophysical properties and soil fertility and cotton yield, as well as for the wide dissemination of positive results.

\section{METHODS OF CONDUCTING THE EXPERIMENT}

Based on the above, composts of different proportions were prepared, and experiments on their effect on soil fertility and cotton yield were conducted in the conditions of typical gray soils of the research and educational experimental farms of Tashkent State Agrarian University.

The field experiment consisted of 9 options, 4 repetitions, which were conducted in the following order. Control option mineral fertilizers $\mathrm{N}_{200} \mathrm{P}_{140} \mathrm{~K}_{100}$ $\mathrm{kg} / \mathrm{ha}$, in the second option additional mineral fertilizers $(\mathrm{NPK})+$ manure $10 \mathrm{t} / \mathrm{ha}$, in option $3 \mathrm{NPK}+$ manure $20 \mathrm{t} / \mathrm{ha}$, in option $4 \mathrm{NPK}+$ compost-1 (rice and wood sawdust-25\%, cattle manure- $25 \%$, poultry manure-45\%, phosphogypsum-5\%) 10 t/ha, option 5 NPK + compost-1, 20 t/ha, option $6 \mathrm{NPK}+$ compost2 (rice and wood sawdust-25\%, cattle manure- $25 \%$, poultry manure $-35 \%$, phosphogypsum-15\%) $10 \mathrm{t} / \mathrm{ha}$, option $7 \mathrm{NPK}+$ compost-2, 20 t/ha, 8-variant compost-3 (rice and wood sawdust-25\%, cattle manure- $25 \%$, poultry manure $-25 \%$, phosphogypsum25\%) $10 \mathrm{t} / \mathrm{ha}$ and option 9 NPK + compost-3, $20 \mathrm{t} / \mathrm{ha}$.

The research was conducted on the basis of "Methods of conducting field experiments" (2007).

\section{RESEARCH RESULTS AND THEIR DISCUSSION}

An analysis of the experimental results showed that over 3 years, the bulk soil mass decreased from $0.05 \mathrm{~g} / \mathrm{cm}^{3}$ to $0.07 \mathrm{~g} / \mathrm{cm}^{3}$ in a $0-30 \mathrm{~cm}$ layer compared to the control (uncomposted) in the version of 20 tons of compost-2 per hectare.

This shows the positive effect of applying 20 tons of compost-2 on improving soil density (Figure $1)$. 


\section{EPRA International Journal of Research and Development (IJRD)

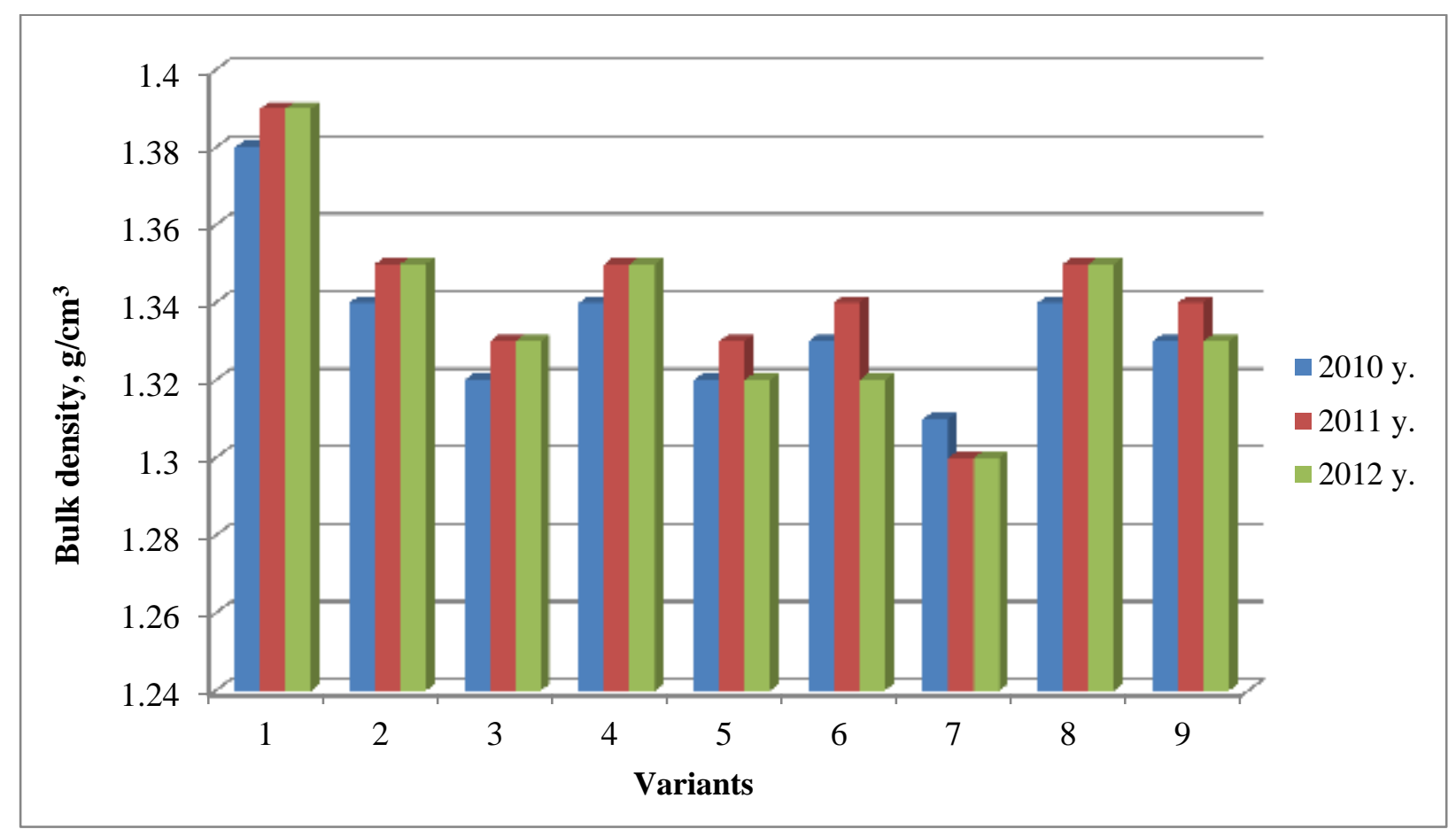

Figure 1. Change in bulk density in the soil layer $0-30 \mathrm{~cm}$ at the end of the growing season when using different composts, $\mathrm{g} / \mathrm{cm}^{3}$

At the end of the exploitation period, in the 7 th variant with 20 tons of compost- 2 per hectare, the porosity in the soil layer of $0-30 \mathrm{~cm}$ was $2.6 \%$ higher than in the control (1) variant and $1.0 \%$ higher than in variant (3), where $20 \mathrm{t} / \mathrm{ha}$ of manure was introduced. And also the use of compost played an important role in restoring the soil structure, having a positive effect on the structural state of the soil and their water resistance. This indicates that the water-physical state of the soil improves when compost is used, instead of using only manure.

The optimal effect of the used composts was observed at the rate of $20 \mathrm{t} / \mathrm{ha}$ of compost-2, the humus content in the soil layers of 0-30 and $30-50 \mathrm{~cm}$ increased by $0.115-0.024 \%$, nitrogen by 0.010 $0.002 \%$ and phosphorus by $0.014-0.003 \%$. In addition, the highest values of nitrate nitrogen, mobile phosphorus and exchange potassium in this embodiment are 24.5 in the soil layer $0-30 \mathrm{~cm}$, respectively; 33.6 and $295 \mathrm{mg} / \mathrm{kg}$ or 3.3 , respectively, compared with the control; 3.8 and $30 \mathrm{mg} / \mathrm{kg}$ were higher.

The better the soil conditions for plants, the faster their growth and early ripening. Cotton growth and development was accelerated in options of 20 tons per hectare of various composts, especially in the variant where compost-2 was used at $20 \mathrm{t} / \mathrm{ha}$, the accumulation of cotton yield elements was higher than in other options.
The main elements that determine the cotton yield are the yield elements, that is, a cotton ball, and the more of them, the higher the yield. As a result of observations, as of September 1, 3-4 cotton ball were collected more in the version with 20 tons of compost-2 per hectare than in the control version.

Based on the foregoing, the effect of various composts on the cotton crop was determined, in which compost- 2 prepared in a ratio of $1: 1: 1.4: 0.6$ to the components of the compost composition was in version 7, where 20 tons per hectare were used, which gives an additional yield of 5-6 c/ha compared to the control variant.

\section{CONCLUSIONS}

Thus, when applying 20 tons of compost-2 per hectare from various wastes in the soil, favorable conditions for cotton are created, and the growth and development of cotton is accelerated, which gives an additional yield of 5-6 c/ha compared to the control variant. It has also been proven that composts are one of the main sources of soil enrichment with organic fertilizers. 


\section{REFERENCES}

1. Ibragimov N.M., Otakulova D., Niyazaliev B.I. (2016), The influence of organicmineral fertilizers on the nutritional regime and productivity of cotton. I International Scientific and Practical Conference "The Current Ecological State of the Natural Environment and Scientific and Practical Aspects of Environmental Management" Collection of articles. February 29th. Solyonoe Zaymishe, pp: 1216-1218. (in Russian).

2. Mirzajonov K., Nurmatov Sh. (2008), Increasing soil fertility. Journal Agroilm. Tashkent, №4 (8), p.p: 1-2. (in Uzbek).

3. www.websadovod.ru/beginners/compost_7. asp.

4. www.aktivzem.com.ua/kompost.php.

5. www.sianie1.ru/PZ/kompost. 